\title{
9. Pacific media under siege A review of the PINA 2018 Summit
}

\begin{abstract}
The rapidly-changing technology and transforming political situation across the Pacific have seen a noticeable shift towards harsher media legislation as governments facing unprecedented scrutiny try to contain the fallout from social media, citizen journalism and fake news. These developments were at the heart of the discussions at the Pacific Islands News Association's PINA 2018 Summit in Nuku'alofa, Tonga, in May. The biannual event is the largest gathering of Pacific Islands journalists to contemplate issues of mutual concern, formulate collective responses and chart the way forward. This article reviews this year's meeting, where discussions centred around the opportunities and challenges of the expanding social media sphere, as well as taking a fresh look at some perennial problems, such as corruption, political pressure and gender violence.
\end{abstract}

Keywords: citizen journalism, corruption, fake news, internet freedom, gender violence, Pacific Islands, Pacific Islands News Association PINA, internet freedom, media ethics, media legislation, social media

\section{GERALDINE PANAPASA and SHAILENDRA SINGH}

The University of the South Pacific, Suva, Fiji

\section{Introduction}

- VERY two years, Pacific Island journalists gather for the biannual Pacific Islands News Association (PINA) Summit to exchange ideas, raise issues of mutual concern, discuss possible solutions and jointly formulate a way forward. The PINA Summit, as the only event of its kind in the Pacific, provides a useful snapshot of the challenges confronting the region's news media sector. This year, as in past years, there was much to discuss, with 99 delegates from 12 of the 19 countries affiliated with PINA attending. Topics for discussions ranged from the challenges posed by the digital media revolution and the role of the media in promoting good governance to climate change, gender violence and the increasingly tough working environment for regional journalists, largely due to hardening government attitudes and tougher legislation. (PINA_Summit_2018_Programme, 2018). 


\section{A meeting place for news media and CSOs}

An interesting element of the Summit is the strong interest shown by non-journalists and non-news media organisations. Attendees included communications managers from regional and international civil society organisations, (CSOs) representatives of development agencies and a range of technical experts. They made up 61 percent of the delegation, which was larger than the journalistic cohort. Their attendance was strong despite the meteoric rise of digital media in the region, with many organisations no longer fully reliant on the mainstream news media for communicating their messages (Finau et al., 2014). Most, if not all, major regional and international organisations boast their own websites and social media pages, creating and distributing their own content and connecting directly with followers (Finau et al., 2014). The heavy presence of the nonjournalism delegates indicated that the mainstream news media were still seen as influential and relevant to their work, even though news media no longer hold a monopoly on news production and dissemination.

The non-journalism participants did not merely contribute to the discussions: as the sponsors of some events, they had prior say in the programme, selecting some workshop topics that were aligned to their organisational mission and thus played a part in setting the Summit's agenda. Typically, the news media guard their independence fiercely and some traditionalists would question the level of $\mathrm{CSO}$ involvement at a gathering for journalists. That being said, there are some realities to contend with: for example, without sponsors, it would be difficult to organise the PINA Summit in the first place. Indeed, besides sponsorship from regional and international organisations, the Summit is often bankrolled by the government of the host country.

Moreover, CSOs not only proliferate in the Pacific, they are an important source for regional news media. The CSOs are often staffed by experts working in developmental areas, who share their specialist knowledge and research findings with media. The CSO involvement makes sense, given the lack of capacity in the Pacific news media sector for in-depth reporting. This shortcoming can be attributed to low salaries, high staff turnover and lack of long-term training and study opportunities (Tacchi, Horst, Papoutsaki, Thomas \& Eggins, 2013). As long as the media maintain their independence and neutrality, their relationship with CSOs can be mutually beneficial. Towards this end, PINA formalised collaboration with the Pacific Islands Development Forum (PIDF) on the sidelines of the Summit. This offered PINA membership of the sub-regional political grouping and a seat at the same table with Pacific leaders, heads of the private sector and civil society organisations. In return, PINA would consider PIDF as an associate member of the regional media body.

In some ways, Pacific CSOs are a natural fit with their news media counterparts, not the least because of their intersecting priorities. An obvious example 
of this is the crusade against corruption, which aligns with the news media's core watchdog role. A two day pre-summit corruption workshop was sponsored by the UN-Pacific Regional Anti-Corruption unit. Another workshop sponsored by the Pacific Environment Journalists Network (PEJN) discussed climate change, reportedly the biggest threat to the Pacific. The workshop on subsistence and commercial agriculture was facilitated by the Tongan Ministry of Agriculture, Food, Forests and Fisheries. Subsistence agriculture is regarded as an important food source in the Pacific, whereas commercial agriculture is seen to hold tremendous potential, but is still underdeveloped. The workshop addressed what useful role, if any, the media could play in reporting the agriculture sector, which receives scant coverage compared with politics, sports and entertainment (PINA_Summit_2018_Programme, 2018).

\section{The digital dilemma}

While the topics were relevant, correlated and fed into the overall theme of the Summit, most concerns centred around the ongoing digital media trends, whose impacts were being widely felt (Finau et al., 2014). These included the loss of advertising revenue caused by a decline in the number of news consumers, and the ongoing government crackdown on social media abuse, news media organisations and professional journalists (Finau et al., 2014).

Mainstream media across the world have lost their monopoly on news production and dissemination, with social media putting the power in people's hands to produce and distribute their own 'news', giving rise to citizen journalism (Patel, 2010). In order to retain news consumers, mainstream media are adapting to the new paradigm by incorporating social media tools into their editorial strategy and business models, with varying levels of success (Patel, 2010). The PINA Summit heard that the news media in most Pacific Island countries had not escaped this trend, even though media digitisation in the region is not as advanced as in developing countries. Pacific Island mainstream media organisations, especially in the larger island countries, were struggling to adapt to this new normal, as they battled declining profits, diminishing readership and waning influence. As a result of this seismic change, important questions about the fate of the news business emerged, especially around print media (PINA, Invitation, 2018)

The Summit heard that the news media were fighting back: Fiji media organisations had jumped on the social media bandwagon in attempts to maintain, if not boost readership. During his presentation at the Summit on 'Twitter-a new form of journalism', Fijian Media Association general secretary Stanley Simpson (Simpson, 2018) observed that Facebook was the most popular platform in Fiji with the masses, and that some news media organisations, which boasted their own Facebook pages, had built a massive following. For example, The Fiji Times embraced social media earlier than most, thus creating a relatively large following 
(141,000 as at September 21). Twitter, while not as popular as Facebook, was gaining ground. Simpson observed that Fiji journalists had taken to Twitter with gusto, tweeting from both their individual accounts and the official media organisation account. Said Simpson:

Fiji journalists are starting to tweet breaking news when they see an event happening live - fire, road accident, etc. They are tweeting quotes from press conferences before they even get back to the office. They are also tweeting headlines or promoting/teasing out stories in their upcoming news bulletins. This allows the public to get news on the go; that is the trend today. (Simpson, 2018)

According to Simpson, the largest Twitter audience in Fiji was the Fiji Rugby Union with more than 74,900 followers, Tourism Fiji with more than 62,600 followers and The Fiji Times with more than 52,300 followers (Simpson, 2018). Other fast-growing profiles on Twitter included Fiji One News with more than 17,500 Twitter followers, FBC TV with just over 11,400 and Fiji Sun with more than 7,200 followers (Simpson, 2018). It's a game of catchup for Pacific Islands news media as the number of internet users worldwide continues to increase by up to seven percent year-on-year, totaling 4.021 billion in 2018 (Kemp, 2018). Social media users in 2018 totaled 3.196 billion while mobile phone users totaled 5.135 billion (Kemp, 2018).

On the subject of social media abuse and the subsequent government crackdown, Tongan Prime Minister 'Akilisi Pōhiva set the tone in his opening address. A former broadcaster/publisher and democracy campaigner, Pōhiva, has been accused of suppressing the media since forming government in 2014. An unrepentant Pōhiva used his platform to draw attention to what he sees as a serious threat; allegations circulating freely on social media, supposedly designed to discredit and destabilise his government. He gave an example of what he termed as false claims of a member of his Cabinet using foul language in an online chat room to denigrate King Tupou, which had created an uproar (Pōhiva, 2018). When journalists questioned him about the relevance of raising matters discussed on social media, given that it was beyond anyone's control, Pōhiva said:

Although social media is beyond our control, it is important that the government addresses issues raised via social media, especially when it can endanger the political stability of our island nation. It is very important that we are all empowered - media and government alike - to deal with the challenges posed by the ever-changing digital world. (Pōhiva, 2018)

While Pōhiva's concerns were widely shared at the Summit, there was also a sense that some governments were cynically using social media abuse as a pretext to impose sweeping censorship to discourage public discussion of 
important national issues on both social and mainstream media. In an effort to regulate 'harmful' social media content, the Tongan government adopted new laws in 2015 for the creation of an internet regulatory agency with the power to block websites without reference to a judge (Reporters Without Borders, 2018).

Just days after the PINA Summit, the Fiji Parliament passed the controversial Online Safety Act 2018 to promote 'responsible online behaviour and online safety' (Nacei, 2018). However, there are concerns about the impact on free speech given Fiji's restrictive media environment. The Summit heard of social media's important role as a platform for discussing issues that the Fiji mainstream media were reluctant to touch (Simpson, 2018). Indeed, one of the major concerns of Fijian citizens who made submissions on the Online Safety Bill was the absence of a clause to protect responsible free speech (Tarai, 2018; Parliamentary Standing Committee on Justice, 2018).

In Samoa, Prime Minister Tuilaepa Maleilegaoi threatened to ban Facebook after what he described as 'gutless anonymous bloggers' using social media to abuse government officials and innocent members of the public (Luamanu, 2018). This included Facebook posts by 'faceless ghosts' making countless allegations of extramarital affairs, corruption and sensitive details about public figures, and their families (Luamanu, 2018). Maleilegaoi claimed that some governments had banned Facebook, but Samoa held back because of social media's positive impact (Luamanu, 2018). Journalists Association of Samoa president Rudy Bartley said personal attacks by 'faceless ghosts' often caused a rift in families and communities. In Bartley's view, the rise of fake news and citizen journalism were major challenges for journalists:

There is a lot of fake news circulating but as a good journalist, you have to use it as part of your new format. There is a responsibility in using social media wisely. (Bartley, 2018)

However, Bartley prefers awareness campaigns to encourage responsible social media usage to draconian legislation that stifles legitimate discussion. In Papua New Guinean, too, authorities considered blocking Facebook due to what were described as defamatory publications, fake news, identity theft and pornography (Tlozek, 2018). At the PINA Summit, PNG's Acting Secretary for the Department of Communication and Information, Paul Korni, said his government would not hesitate to legislate social media in order to put a tight lid on fake news and other defamatory publications (Panapasa, 2018).

Korni revealed that some sorcery-related attacks in PNG were linked to social media, in particular Facebook posts that openly encouraged mobs to attack and kill people suspected of witchcraft (Blades, 2018). He also decried the use of social media platforms to attack politicians: 
In my country, there is a realisation that social media is doing far greater damage to the integrity of politicians and leaders. If you use social media to attack political leaders then of course those leaders have authority to say we will put a lid on the freedoms. (Korni, 2018).

While sharing Korni's concerns about some of the excesses on social media, journalists and publishers at the Summit noted that news media were not involved in the abuse, bound as they are by professional protocols, yet they would be inevitably caught up in any restrictive legislation. Solomon Star publisher and operations manager Hilda Lamani was concerned about the fallout of any social media legislation on mainstream news media, and social media's effect on the work and integrity of journalists. She said the reliance on social media and citizen journalism was fueling fake news, which created a trap for journalists.

Journalists need to be aware of the social media costs following media regulation (introduced) in other countries. Cultural barriers limit the usage of social media, which takes away face-to-face communication-meeting people and understanding their needs. We write stories taken from social media, not understanding the livelihood of those who are affected. (Lamani, 2018)

Tongan journalist and democracy campaigner Kalafi Moala pushed for more education and less legislation:

Instead of monitoring, we need to continue to educate people to tell the truth. It is telling the truth and authenticity that will expose the fake. I have never seen social media as a threat to journalism. I see it as an extension of the media when it is used properly. (Moala, 2018)

Notwithstanding Lamani and Moala's sentiments, some regional governments clearly prefer tougher legislation, despite concerns that such legislation, often backed by jail terms and hefty fines, could have a chilling effect on journalism.

\section{Corruption and political intimidation}

The Summit heard that the old, politically-motivated threats faced by journalists who dared to scrutinise governments and other powerful figures were still very much part of the Pacific media landscape. In one parallel session on members under threat, several Pacific Island journalists and communication officers shared first-hand experiences of what they encountered in the course of carrying out their watchdog role. The session heard that journalists and media organisations that were targeted the most were those making an impact in society by holding power to account. Some panelists spoke about intimidation and illegal detention by police and politicians who were unhappy with what 
was published. One Tongan journalist talked about how asking tough questions resulted in her removal from the newsroom to the advertising section, while another from Papua New Guinea spoke about legal threats and physical assaults dished out by politicians and their supporters because of a story they did not agree with. Tongan media veteran Moala said autocratic governments were still the biggest threat facing Pacific media:

The real threat facing every media in the Pacific is the threat from government, whether it is Papua New Guinea, Vanuatu, Fiji, Tonga or Samoa. (Moala, 2018)

The problem that has consistently earned media the ire of governments is corruption, one of the most persistent and challenging issues in the Pacific Islands. During a presentation on the role of the media in oversight and accountability, Mihaela Stojkoska, the anti-corruption specialist with the United Nations Regional Anti-Corruption Project (UN-PRAC), said the objectives of the Pacific framework for Pacific regionalism included strengthening governance and legal systems to ensure safety (Stojkoska, 2018). Stojkoska said that among the institutions most affected by corruption at the global level were the judiciary and police. Corruption, bribery, theft and tax evasion cost developing countries about US\$1.26 trillion each year, money could be used to lift those who are living on less than US\$1.25 a day above US\$1.25 for at least six years (Stojkoska, 2018).

As we argued at the summit in our own presentation, in some Pacific countries corruption is prevalent in government sectors, including the police, customs, minerals sector, fisheries and forests. In the Pacific, corruption manifested itself in a variety of forms, such as petty corruption, embezzlement, nepotism and the creation of patronage networks. Delegates were reminded that corruption diverts expenditure from key public goods, weakens poverty-reduction efforts and undermines political legitimacy and stability.

We argued that while there was a need to prioritise news coverage and address corruption from a variety of angles for maximum impact, competing newsroom priorities, lack of time and resources, lack of journalistic capacity and unethical journalists or media owners were hindering coverage. A sound knowledge of media law and ethics was deemed vital for reporting corruption effectively and safely, in terms of avoiding lawsuits or losing public trust credibility.

Plausible solutions to these issues were also discussed, including encouraging journalists and media owners to prioritise corruption reporting, negotiating for time and space with the editor, training and workshops, as well as institutionalstrengthening and increased public awareness campaigns.

Delegates were told that journalistic scrutiny acted a deterrent to corruption and that the core media role, based on the traditional Fourth Estate principle, was 
geared towards keeping government accountable. Without the scrutiny, government was no longer accountable to the people and would act with impunity.

\section{Gender-based violence}

Gender-based violence emerged as another major concern, with the news media urged to take a stronger line against this form of abuse. Data tabled by NZ Pacific Media Network senior journalist Lisa Williams indicated that two out of every three Pacific women would experience violence (Williams, 2018). With regards to media coverage, Williams said there were issues concerning verification of facts and upholding ethics with regards to the protection of victims (Williams, 2018). She said the gender dimensions of violence had also shifted to social media, with issues of such as cyber bullying, online harassment and 'flaming' of women who voiced an opinion. Her concern, shared by many others, was the number of closed groups that existed online, social media groups that did not have a public face. The anonymity encouraged cyber-bullying, a major problem for some women in the online sphere, particularly over their opinions on a particular issue. Stated Williams:

Combine this with structural discrimination and women being denied an education and you have the perform storm of conditions for violence against women. (Williams, 2018)

As a multimedia journalist, Williams also highlighted the advantages of cyberjournalism, such as providing the platform to find story angles, leads and information from the online community of Pacific voices, which opened the path to investigative journalism into issues concerning gender-based violence.

Tonga Women's Crisis Centre community education advocate Lesila To'ia provided a snapshot of the grave situation in the Pacific Island kingdom. Social media in Tonga played a positive role. Tongan women used Facebook to highlight instances of gender-based violence, which alerted the Crisis Centre about the extent of the problem. The cases involved the sexual exploitation of women who had recently come out of personal relationships. The impact on some of the female victims of online bullying, harassment and victimisation was devastating, with some young women considering suicide (To'ia, 2018).

Williams' and To'ia's presentations underlined the inadequacy of genderbased violence reporting, and the need for specialised training for journalists to focus on this particular area, using social media as a tool to create awareness.

\section{PINA's challenges and future directions}

A major Summit event was the tabling of the review of PINA's 2013-2016 Strategic Plan, which set the benchmark for the development of the new five-year, 2017- 
2021 Strategic Plan. The review found that while the stakeholders were generally satisfied, there was consensus that PINA was seen as a 'news only' organisation, and that more needed to be done to change this impression (PINA, 5th Pacific Media Summit Outcomes Statement, 2018). The report recommended that PINA increase its advocacy for freedom of the media and freedom of expression.

Another key recommendation was strengthening links between the region's national media associations. Two new associations were launched at the sidelines of the Summit, the Media Association of Tonga (MAT) and the Pacific Environment Journalist Network (PEJN). MAT saw the coming together of two rival Tongan media organisations while PEJN signaled the arrival of the Earth Journalism Network (EJN) in the Pacific. The new group aims to provide support, resources and training for journalists interested in reporting environmental issues. PEJN will be supported by the Earth Journalism Network (EJN), which was also keen to formalise a memorandum of understanding with PINA.

The review emphasised the need to boost PINA's numbers by retaining existing membership, seeking out new members and encouraging former members to return to the PINA fold, especially in light of a decline in subscription revenue. It also recommended improving relationships with the region's journalism schools. (PINA, 5th Pacific Media Summit Outcomes Statement, 2018).

\section{Conclusion}

The 2018 PINA Summit provided a window into the state of the Pacific Islands news media sector, and the picture is not a pretty one. Besides coming under political pressure for reporting long-standing problems in the region, such as corruption, the news media is also challenged by social media, both financially and in terms of harsher legislation being proposed or implemented by some regional governments. Gender violence emerged as another major concern in the region, and the need for the news media to step up and create greater awareness about this problem. Among the reaffirmations and commitments made at the 2018 PINA Summit was a general consensus that media practitioners and journalists had to exercise a higher degree of responsibility when incorporating digital media and new media in their work processes. In the current climate, PINA's recommendation for greater support for media freedom issues in the Pacific is quite timely, and should be seriously considered. However, the question remains: How can the Pacific media make social media an effective form of journalism? The onus is on journalists and media workers to adapt and embrace these current media practices without compromising their ethics and code of conduct as the Fourth Estate. 


\section{References}

Bartley, R. (2018, May 9). Journalism and fake news. (I. A. Grow., Interviewer)

Blades, J. (2018, January 26). Social media speculation linked to PNG sorcery related attacks. RNZ Pacific. Retrieved from https:/www.radionz.co.nz/international/programmes/datelinepacific/audio/2018629484/social-media-speculation-linked-to-pngsorcery-related-attacks

Finau, G., Prasad, A., Kant, R., Tarai, J., Logan, S., \& Cox, J. (2014) Social media and e-democracy in Fiji, Solomon Islands and Vanuatu. In 20th Americas Conference on Information Systems, AIS (Association for Information Systems), Savannah, GA: AIS.

Kemp, S. (2018, January 30). 2018 Global digital report. Retrieved from Wearesocial. com https://wearesocial.com/uk/blog/2018/01/global-digital-report-2018

Korni, P. (2018, May 9). PINA 5th Pacific Media Summit. (P. S. 1, Interviewer)

Lamani, H. (2018, May 9). New media and print management. (G. Panapasa, Interviewer)

Luamanu, J. (2018, March 31). PM threatens to ban Facebook. Samoa Observer. Retrieved from http://www.samoaobserver.ws/en/01_04_2018/local/31711/PM-threatens-toban-Facebook.htm

Moala, K. (2018, May 9). New media and fake news. (G. Panapasa, Interviewer)

Nacei, L. (2018, May 17). Online Safety Bill passed. Fiji Times Online. Retrieved from http://www.fijitimes.com/online-safety-bill-passed/

Nou, K. (2018, May 25). Plans to improve partnership with regional schools of journalism. (G. Panapasa, Interviewer)

Panapasa, G. (2018, June 14). Pacific news journalists grapple with challenges of social media, harsh laws. Asia Pacific Report. Retrieved from https://asiapacificreport.nz/2018/06/14/ pacific-news-journalists-grapple-with-challenges-of-social-media-harsh-laws/

Parliamentary Standing Committee on Justice, L. a. (2018, May). Standing Committee on Justice, Law and Human Rights - Report on the Online Safety Bill 2018. Retrieved from Parliament of the Republic of Fiji http:/www.parliament.gov.fj/wp-content/ uploads/2018/05/Standing-Committee-on-JLHR-Report-on-the-Online-Safety-BillNo-7-of-2018-part-1.pdf

Patel, A. (2010). The survival of the newspaper in the digital age of communication. Unpublished honours thesis, New York, NY: New York University, 2010. Retrieved from www.stern.nyu.edu/sites/default/files/assets/documen ts/con_043010.pdf

PINA. (2004, November). Pacific Islands News Association. Retrieved from http://www. pina.com.fj/index.php? $\mathrm{p}=$ pina\&m=about-us

PINA. (2018). 5th Pacific Media Summit Outcomes Statement. Suva: Pacific Islands News Association (PINA).

PINA. (2018, May 7). Invitation to the 5th Pacific Media Summit. Retrieved from http:// www.pina.com.fj/downloads/Pacific_Media_Summit_2018_Invitation.pdf

PINA. (2018, May 25). PINA to improve partnership with regional schools of journalism. Samoa Planet. Retrieved from http://www.samoaplanet.com/pina-improvepartnership-regional-schools-journalism/

PINA_Summit_2018_Programme. (2018, May 7). Retrieved from PINA http://www. pina.com.fj/downloads/PINA_Summit_2018_Programme.pdf

Pōhiva, S. 'A. (2018, May 8). PM’s Opening Address. 5th Pacific Media Summit Nuku'alofa, Tonga.

Reporters Without Borders. (2018). Tonga: Independent watchdog. Retrieved from Reporters Without Borders https://rsf.org/en/tonga

Simpson, S. (2018). Twitter-A new form of journalism. 5th PINA Media Summit. Nuku'alofa, Tonga. 
Singh, S. (2017). State of the media review in four Melanesian countries-Fiji, Papua New Guinea, Solomon Islands and Vanuatu_-in 2015. SSGM Discussion Paper 2017. Canberra, ACT: ANU.

Statista (2018). Number of monthly active Facebook users worldwide as of 1st quarter 2018 (in millions). The Statistics Portal. Retrieved from https://www.statista.com/ statistics/264810/number-of-monthly-active-facebook-users-worldwide/

Stojkoska, M. (2018, May 7). The role of media in oversight and accountability. 5th Pacific Media Summit 2018. Nuku'alofa, Tonga: UN-PRAC.

Tacchi, J., Horst, H., Papoutsaki, E., Thomas, V., \& Eggins, E. (2013). PACMAS state of the media and communication regional report 2013. Melbourne: PACMAS/ABC International.

Tarai, J. (2018, March 28). Submission-Online Safety Bill 2018. Retrieved from https:// jopetarai.com/2018/03/28/submission-online-safety-bill-2018/

Tlozek, E. (2018, May 29). Papua New Guinea considers ‘temporary’ ban on Facebook, citing illegal use. ABC News. Retrieved from http://www.abc.net.au/news/2018-0529/png-considers-temporary-ban-on-facebook/9813506

To'ia, L. (2018, May 9). Reporting gender-based violence through the media - challenges and solutions. 5th Pacific Media Summit 2018. Nuku'alofa, Tonga.

Williams, L. (2018, May 9). 5th Pacific Media Summit, 2018 (P. S.-b. Media, Interviewer)

Geraldine Panapasa is editor-in-chief of the Wansolwara journalism newspaper and an assistant lecturer at The University of the South Pacific.

geraldine.panapasa@usp.ac.fj

Dr Shailendra Singh is senior lecturer and discipline coordinator of journalism, School of Language, Arts and Media, The University of the South Pacific, Suva, Fiji. He is also on the editorial board of Pacific Journalism Review and a research associate of the Pacific Media Centre.

shailendra.singh@usp.ac.fj 